Ethos: Jurnal Penelitian dan Pengabdian kepada Masyarakat, Vol 9, No.2, Juni 2021: 288-295

\title{
KebUtUhan Kegiatan Webinar TENTANg DiSPOSISI BERPIKIR
}

\author{
${ }^{1}$ Yayan Eryk Setiawan \\ ${ }^{1}$ Program Studi Pendidikan Matematika, FKIP, Universitas Islam Malang, Jawa Timur, Indonesia \\ email: ' $y a y a n e r y k s e t i a w a n @ u n i s m a . a c . i d$
}

\begin{abstract}
This thinking disposition is important for a teacher and prospective teacher. However, there a prospective teacher who understands the thinking disposition. Therefore, it is important to conduct a webinar to equip prospective teachers about thinking dispositions. Before the webinar activity is carried out, it is necessary to analyze the needs for the implementation of the webinar on thinking disposition. Therefore, the purpose of this study is needed analyze implementing a webinar activity on thinking dispositions. This research method is quantitative research with a survey approach. This survey was conducted on 84 respondents consisting of 69 undergraduate students, 1 doctoral student, 10 teachers, and 4 lecturers. The survey data collected in this study consisted of questionnaire data about respondents' knowledge of thinking dispositions and their opinions in participating in webinar activities of thinking dispositions. The data of questionnaire results show that the knowledge of respondents about the thinking disposition is $38.45 \%$ which is in the very low category. Data of respondents' opinions show that $50 \%$ of respondents do not know about thinking dispositions and $42 \%$ of respondents know little about thinking dispositions. Thus the results of the questionnaire and respondents' opinions indicate that a webinar activity of thinking dispositions is needed which aims to increase students' knowledge of thinking dispositions.
\end{abstract}

Keywords: needs analysis, webinar, thinking disposition.

\begin{abstract}
Abstrak. Disposisi berpikir ini penting untuk dimiliki oleh seorang guru dan mahasiswa calon guru. Akan tetapi, masih sedikit mahasiswa calon guru yang memahami tentang disposisi berpikir. Oleh karena itu, penting untuk dilaksanakan webinar dalam rangka membekali mahasiswa calon guru tentang disposisi berpikir. Sebelum kegiatan webinar dilakukan, terlebih dahulu dilakukan analisis kebutuhan pelaksanaan webinar tentang disposisi berpikir. Oleh karena itu, tujuan penelitian ini adalah melakukan analisis kebutuhan pelaksanaan kegiatan webinar tentang disposisi berpikir. Metode penelitian ini adalah penelitian kuantitatif dengan pendekatan survei. Survei ini dilakukan terhadap 84 responden yang terdiri dari 69 mahasiswa S1, 1 mahasiswa S3, 10 Guru, dan 6 Dosen. Data hasil survei yang dikumpulkan dalam penelitian ini terdiri dari data angket tentang pengetahuan responden terhadap disposisi berpikir dan pendapatnya dalam mengikuti kegiatan webinar tentang disposisi berpikir. Data yang berupa hasil angket menunjukkan bahwa pengetahuan responden tentang disposisi berpikir sebesar 38,45\% yang berada pada kategori sangat rendah. Data yang berupa pendapat responden menunjukkan bahwa $50 \%$ responden belum mengetahui tentang disposisi berpikir dan $42 \%$ responden hanya mengetahui sedikit tentang disposisi berpikir. Dengan demikian, hasil pengisian angket dan pendapat responden menunjukkan bahwa dibutuhkan adanya kegiatan webinar tentang disposisi berpikir yang bertujuan untuk meningkatkan pengetahuan mahasiswa tentang disposisi berpikir.
\end{abstract}

Kata Kunci: analisis kebutuhan, webinar, disposisi berpikir.

\section{Pendahuluan}

Seorang pelajar hendaknya tidak hanya dibekali kemampuan berpikir, tetapi juga harus dibekali dengan keterampilan berpikir. Keterampilan berpikir ini oleh beberapa peneliti disebut dengan disposisi berpikir 
(Perkins et al., 1993; Ron, 2001; Setiawan, 2020d; Tishman et al., 1993; Tishman \& Andrade, 1995). Berbagai hasil penelitian menunjukkan bahwa disposisi berpikir ini memengaruhi keberhasilan seorang pelajar dalam belajar atau dalam menyelesaikan soalsoal (Almerino, Etcuban, Jose, \& Almerino, 2019; Hästö, Palkki, Tuomela, \& Star, 2019; Karademir, 2019; Kele \& Sharma, 2014; RittleJohnson \& Star, 2007; Star \& RittleJohnson, 2008). Oleh sebab itu, disposisi berpikir ini penting untuk dibelajarkan kepada siswa atau mahasiswa agar berhasil dalam belajar.

Akan tetapi, sebelum membelajarkan tentang disposisi berpikir, seorang calon pendidik harus mengetahui tentang disposisi berpikir. Hasil penelitian menunjukkan bahwa seorang calon guru yang memiliki disposisi berpikir lebih yakin dalam melakukan pembelajaran di kelas (Clark et al., 2014). Keyakinan ini memengaruhi secara signifikan dari keberhasilan seseorang dalam melakukan kegiatan ataupun menyelesaikan masalah (Almerino et al., 2019). Bahkan, hasil penelitian menunjukkan bahwa hanya sedikit mahasiswa calon guru matematika yang dapat memunculkan disposisi berpikirnya dalam menyelesaikan masalah matematika (Setiawan et al., 2020a). Dengan demikian, sangat penting bagi seorang calon pendidik untuk mengetahui tentang disposisi berpikir. Pengetahuan awal tentang disposisi berpikir yang dibutuhkan, baik oleh seorang pendidik maupun calon pendidik di antaranya adalah asal mula disposisi berpikir, tinjauan filosofis dan psikologis dari disposisi berpikir, definisi disposisi berpikir secara filosofis dan psikologis, konteks disposisi berpikir, hubungan dan perbedaan disposisi berpikir dengan kemampuan berpikir, istilah lain dari disposisi berpikir, serta perbedaan disposisi berpikir dengan kebiasaan berpikir (Ron, 2001; Setiawan, 2020d).

Dalam rangka membekali pendidik dan calon pendidik dengan pengetahuan awal tentang disposisi berpikir yang dibutuhkan tersebut, peneliti akan mengadakan kegiatan pengabdian kepada masyarakat yang berupa kegiatan seminar tentang disposisi berpikir. Akan tetapi pada masa pandemi Covid-19 ini, kegiatan seminar tidak mungkin untuk dilakukan karena untuk mencegah penularan Covid-19. Sebagai pengganti kegiatan seminar tersebut, peneliti akan mengadakan webinar. Kegiatan webinar ini didefinisikan sebagai kegiatan yang merujuk pada kegiatan seminar secara daring atau 'dalam jaringan dengan menggunakan aplikasi tertentu yang berbasis pada internet. Kegiatan webinar ini memiliki beberapa keunggulan, yaitu biaya yang dikeluarkan lebih murah daripada kegiatan seminar dan jangkaun lebih luas. Akan tetapi, kegiatan webinar ini sangat bergantung pada koneksi internet. Oleh karena itu, penting untuk menyedikan koneksi internet yang kuat dalam pelaksanaan webinar. Dengan demikian, melalui webinar ini, harapannya adalah pengetahuan awal tentang disposisi berpikir ini dapat dipahami dengan baik oleh para pendidik atau calon pendidik.

Sebelum kegiatan webinar tentang tinjaun filosofis dan psikologis dari disposisi berpikir dilaksanakan, penting untuk dilakukan penelitian pendahuluan untuk mengetahui tingkat kebutuhan pendidik dan calon pendidik terhadap pelaksanaan kegiatan webinar ini. Oleh karena itu, penelitian ini bertujuan untuk mengetahui tingkat kebutuhan pendidik dan calon pendidik terhadap kegiatan webinar tentang disposisi berpikir.

Hasil penelitian ini akan bermanfaat sebagai dasar untuk 
memetakan materi webinar dan untuk menetapkan capaian kegiatan webinar dalam rangka meningkatkan pemahaman peserta terhadap disposisi berpikir. Selain itu, hasil penelitian ini dapat dimanfaatkan oleh para dosen yang akan melakukan kegiatan webinar dengan tema disposisi berpikir. Dengan demikian, diharapkan tingkat kebutuhan pendidik dan calon pendidik terhadap pelaksanaan kegiatan webinar tentang disposisi berpikir dapat teridentifikasi dengan baik.

\section{Metode Ilmiah}

Sesuai dengan tujuan penelitian ini, yaitu untuk mengetahui kebutuhan adanya webinar tentang disposisi berpikir, metode penelitian yang sesuai adalah penelitian kuantitatif dengan pendekatan survey. Hal ini sesuai dengan pendapat Creswell (2012) yang mengatakan bahwa penelitian survey merupakan penelitian yang paling sesuai untuk mengidentifikasi kebutuhan dari suatu komunitas. Selain itu, penelitian survey juga dapat digunakan untuk mengetahui pendapat seseorang tentang masalah tertentu (Creswell, 2012). Oleh karena itu, melalui pendekatan survey ini, kebutuhan adanya webinar tentang disposisi berpikir dapat teridentifikasi.

Prosedur penelitian ini terdiri dari 3 tahap (lihat Gambar 1), yaitu: (1) tahap perencanaan, (2) tahap pengumpulan data, dan (3) tahap analisis data. Tahap pertama adalah tahap perencanaan. Pada tahap perencanaan ini, peneliti menyiapkan angket yang digunakan untuk mengetahui pengetahuan awal responden. Angket kebutuhan ini terdiri dari 11 pertanyaan yang harus diisi oleh responden. Masingmasing pertanyaan menggunakan pilihan Tidak Mengetahui (TM), Sedikit Mengetahui (SeM), Mengetahui (M), dan Sangat Mengetahui (SaM). Masingmasing diberikan skor 1, 2, 3, 4 .
Tahap kedua dalam penelitian ini adalah pengumpulan data. Data yang dikumpulkan dalam penelitian ini terdiri dari hasil angket dan pendapat dari responden penelitian. Prosedur pengumpulan data yang berupa hasil angket dilakukan dengan meminta sampel penelitian secara sukarela dan jujur mengisi angket dalam bentuk google form mengenai pengetahuan awal tentang disposisi berpikir. Hasil pengisian angket dalam bentuk google form inilah yang selanjutnya diperoleh data hasil angket. Sementara itu, pendapat dari sampel penelitian diperoleh dengan cara meminta responden untuk memberikan pendapatnya terhadap pelaksanaan kegiatan webinar tentang disposisi berpikir.

Responden dalam penelitian ini adalah dosen, guru, dan mahasiswa S1, S2, S3 yang secara sukarela berpartisipasi dalam mengisi angket kebutuhan akan adanya webinar tentang disposisi berpikir. Sampel penelitian ini secara umum terdiri dari 84 orang yang terbagi dalam 69 mahasiswa S1, 1 mahasiswa S3, 10 Guru, dan 4 Dosen. Mahasiswa S1 ini kebanyakan dari program studi pendidikan matematika. Sementara itu, guru lebih banyak dari guru SMP dan SMA. Rancangan penelitian survey ini menggunakan desain cross-sectional, yaitu peneliti mengumpulkan data dalam satu waktu untuk mendapatkan pengetahuan awal tentang disposisi berpikir yang digunakan untuk menentukan kebutuhan adanya kegiatan webinar tentang disposisi berpikir (Creswell, 2012). 


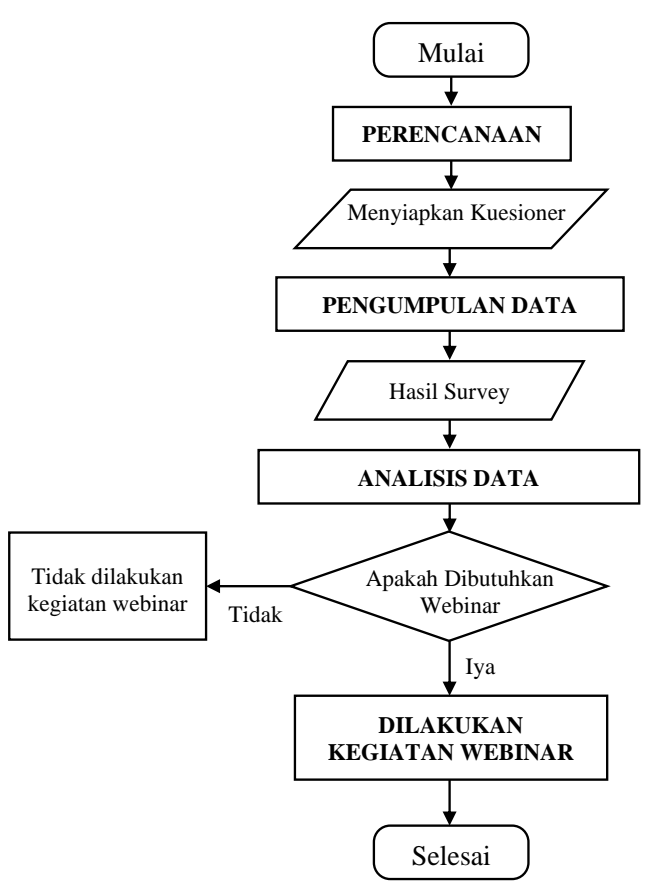

Gambar 1. Tahapan Penelitian

Tahap ketiga dari penelitian ini adalah menganalisis data hasil survey tentang kebutuhan webinar. Terdapat 84 responden yang mengisi angket tersebut. Dari hasil pengisian angket, maka diperoleh skor minimum adalah 924 dan skor maksimum adalah 3.696. Sementara itu, skor minimum dari satu pertanyaan adalah 84 dan skor maksimumnya adalah 336. Dari skor minimum dan skor maksimum ini akan ditentukan kategori kebutuhan untuk diadakannya webinar tentang disposisi berpikir dengan menggunakan interval sangat rendah, rendah, tinggi, dan sangat tinggi. Penentuan interval tersebut menggunakan kuartil, yaitu total skor yang diperoleh di bawah kuartil 1 adalah sangat rendah, di bawah kuartil 2 adalah rendah, di bawah kuartil 3 adalah tinggi, dan di atas kuartil 3 adalah sangat tinggi. Dari interval tersebut diperoleh kategori kebutuhan pelaksanaan kegiatan webinar tentang disposisi berpikir yang dapat dilihat dalam Tabel 1.

Tabel 1.

Kategori Kebutuhan Pelaksanaan Webinar Tentang Disposisi Berpikir

\begin{tabular}{llll}
\hline \multicolumn{1}{c}{ Skor Keseluruhan } & \multicolumn{1}{c}{ Skor Pertanyaan } & Kategori Pengetahuan & \multicolumn{1}{c}{ Keterangan } \\
\hline $924 \leq x<1,617$ & $84 \leq x<147$ & Sangat Rendah & Sangat dibutuhkan webinar \\
$1.617 \leq x<2.310$ & $147 \leq x<210$ & Rendah & Dibutuhkan webinar \\
$2.310 \leq x<3.003$ & $210 \leq x<273$ & Tinggi & Tidak dibutuhkan webinar \\
$3.003 \leq x \leq 3.696$ & $273 \leq x \leq 336$ & Sangat Tinggi & Sangat tidak dibutuhkan webinar \\
\hline
\end{tabular}

Berdasarkan Tabel 1 diperoleh batas kategori kebutuhan pelaksanaan kegiatan webinar tentang disposisi berpikir. Jika pengetahuan responden berada pada kategori rendah atau sangat rendah, dibutuhkan kegiatan webinar mengenai disposisi berpikir ini.

\section{Hasil dan Pembahasan}

Data yang dikumpulkan dalam penelitian ini terdiri dari hasil pengisian angket tentang pengetahuan responden terhadap disposisi berpikir dan pendapat dari responden mengenai pelaksanaan webinar tentang disposisi berpikir. Data pertama yang berupa hasil pengisian angket tentang pengetahuan terhadap disposisi berpikir yang diisi oleh 84 responden dapat dilihat dalam Tabel 2.

\section{Tabel 2}

Hasil Pengisian Angket Pengetahuan Tentang Disposisi Berpikir

\begin{tabular}{llc}
\hline No. & \multicolumn{1}{c}{ Pertanyaan } & Skor \\
\hline 1. & $\begin{array}{l}\text { Apakah Bapak/Ibu Mengetahui } \\
\text { asal mula disposisi berpikir? }\end{array}$ & 139 \\
2. & $\begin{array}{l}\text { Apakah Bapak/Ibu mengetahui } \\
\text { tinjauan filosofis dari disposisi } \\
\text { berpikir? }\end{array}$ & 125 \\
3. $\quad \begin{array}{l}\text { Apakah Bapak/Ibu mengetahui } \\
\text { tinjauan psikologis dari disposisi }\end{array}$ & 127 \\
berpikir? & \\
4. $\quad \begin{array}{l}\text { Apakah bapak/Ibu mengetahui } \\
\text { bahwa definisi disposisi berpikir } \\
\text { bergantung pada konteksnya? }\end{array}$ & 132 \\
Apakah Bapak/Ibu mengetahui \\
konteks yang sesuai untuk \\
mendefinisikan disposisi berpikir
\end{tabular}




\begin{tabular}{ll} 
6. & $\begin{array}{l}\text { Apakah Bapak/Ibu mengetahui } \\
\text { hubungan disposisi berpikir } \\
\text { dengan kemampuan berpikir }\end{array}$ \\
7. $\begin{array}{l}\text { Apakah Bapak/Ibu mengetahui } \\
\text { perbedaan disposisi berpikir } \\
\text { dengan kemampuan berpikir? }\end{array}$ & 130 \\
8. $\quad \begin{array}{l}\text { Apakah Bapak/Ibu mengetahui } \\
\text { istilah lain dari disposisi berpikir? }\end{array}$ & 130 \\
9. $\quad \begin{array}{l}\text { Apakah Bapak/Ibu mengetahui } \\
\text { definisi disposisi berpikir dari } \\
\text { perspektif filsafat? }\end{array}$ & 118 \\
10. $\begin{array}{l}\text { Apakah Bapak/Ibu mengetahui } \\
\text { definisi disposisi berpikir dari } \\
\text { perspektif psikologi? }\end{array}$ & 116 \\
11. $\begin{array}{l}\text { Apakah bapak/Ibu mengetahui } \\
\text { perbedaan dari disposisi berpikir } \\
\text { dengan kebiasaan berpikir? }\end{array}$ & 126 \\
\hline \multicolumn{1}{c}{ Skor Total } \\
\hline
\end{tabular}

Dari Tabel 2 dapat dilihat bahwa skor total hasil pengisian angket yang dilakukan oleh 84 responden adalah 1.421. Berdasarkan Tabel 1 diperoleh bahwa pengetahuan responden terhadap disposisi berpikir secara umum berada pada kategori sangat rendah sehingga sangat dibutuhkan pelaksanaan webinar tentang disposisi berpikir. Persentase total pengisian angket ini adalah 38,45\%.

$$
\text { Persentase pengetahuan }
$$
responden ini secara khusus dapat dilihat pada masing-masing pertanyaan yang dapat dilihat dalam Gambar 2. Dari Gambar 2 dapat dilihat bahwa persentase skor pengetahuan responden tentang asal mula disposisi berpikir adalah 41,37\%. Persentase skor pengetahuan responden tentang tinjauan filosofis dari disposisi berpikir adalah $37,20 \%$. Persentase skor pengetahuan responden tentang tinjauan psikologis dari disposisi berpikir adalah $37,80 \%$. Persentase skor pengetahuan responden tentang definisi disposisi berpikir bergantung pada konteksnya adalah 39,29\%. Persentase skor pengetahuan responden tentang konteks yang sesuai untuk mendefinisikan disposisi berpikir adalah 38,70\%. Persentase skor pengetahuan responden tentang hubungan disposisi berpikir dengan kemampuan berpikir adalah $41,67 \%$. Persentase skor pengetahuan responden tentang perbedaan disposisi berpikir dengan kemampuan berpikir adalah 41,07\%. Persentase skor pengetahuan responden tentang istilah lain dari disposisi berpikir adalah $38,70 \%$. Persentase skor pengetahuan responden tentang definisi disposisi berpikir dari perspektif filsafat adalah $35,12 \%$. Persentase skor pengetahuan responden tentang definisi disposisi berpikir dari perspektif psikologi adalah $34,52 \%$. Persentase skor pengetahuan responden tentang perbedaan disposisi berpikir dengan kebiasaan berpikir adalah 37,50\%. Ini artinya, setiap pengetahuan responden pada masingmasing pertanyaan berada pada kategori sangat rendah. Oleh sebab itu, dibutuhkan dalam webinar untuk menyampaikan 11 pengetahuan yang dibutuhkan oleh pendidik atau calon pendidik untuk memahami disposisi berpikir.

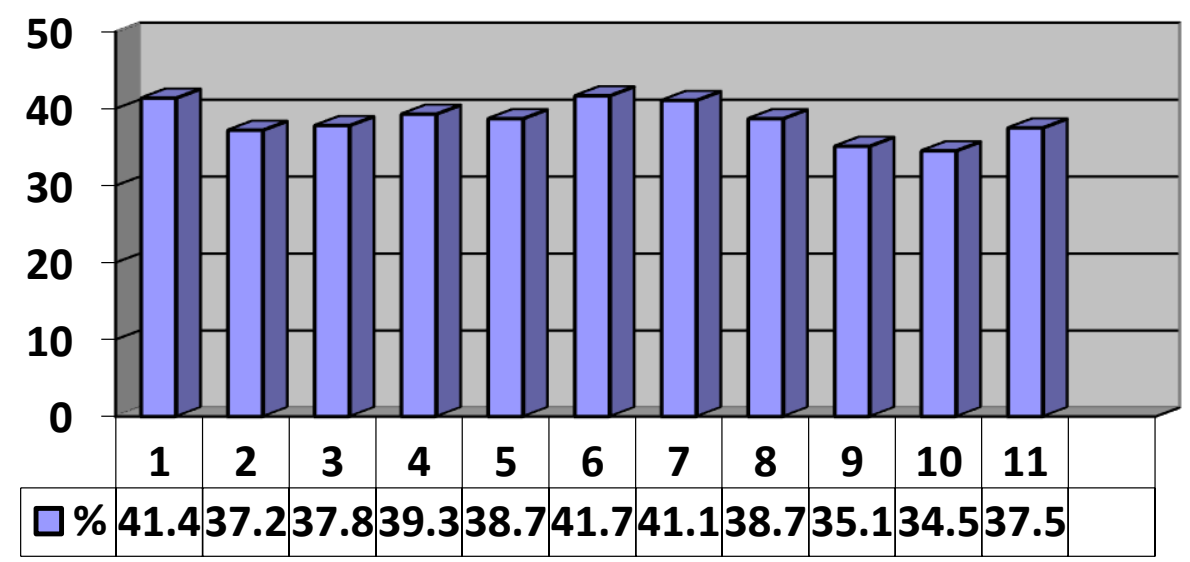

Gambar 2. Diagram Persentase Pengetahuan Responden Tentang Disposisi Berpikir 
Data kedua yang dikumpulkan dalam penelitian ini adalah pendapatpendapat responden mengenai apa yang ingin didapatkan dalam kegiatan webinar tentang disposisi berpikir. Dari 84 responden, diperoleh 78 responden yang memberikan pendapatnya terkait kegiatan webinar yang akan dilakukan tentang disposisi berpikir. Sementara itu, 6 responden tidak memberikan pendapatnya. Pendapat dari 78 responden tersebut dapat dilihat dalam Tabel 3.

Dari Tabel 3 dapat diketahui bahwa dari 78 responden yang memberikan pendapat diperoleh $50 \%$ responden ingin mendapatkan pengetahuan baru tentang disposisi berpikir. Ini artinya ada $50 \%$ responden belum mengetahui tentang disposisi berpikir. Dari Tabel 3 juga dapat dilihat bahwa terdapat $42 \%$ responden ingin memperdalam pengetahuannya mengenai disposisi berpikir. Ini artinya ada $42 \%$ responden yang memiliki sedikit pengetahuan tentang disposisi berpikir. Sementara itu, sisanya yaitu $7 \%$ ingin mendapatkan ilmu yang bermanfaat dan menjadi pendidik yang kompeten.

Tabel 3.

\section{Pendapat Responden Dalam Mengikuti Kegiatan Webinar Tentang Disposisi Berpikir}

\begin{tabular}{ll}
\hline \multicolumn{1}{c}{ Pendapat } & $\begin{array}{l}\text { Banyak } \\
\text { Responden }\end{array}$ \\
\hline $\begin{array}{l}\text { Ingin mendapatkan pengetahuan } \\
\text { tentang disposisi berpikir yang } \\
\text { belum diketahui }\end{array}$ & 39 \\
$\begin{array}{l}\text { Ingin mendapatkan pengetahuan } \\
\text { lebih mendalam tentang disposisi } \\
\text { berpikir }\end{array}$ & 33 \\
$\begin{array}{l}\text { Ingin mendapatkan ilmu yang } \\
\text { bermanfaat }\end{array}$ & \\
$\begin{array}{l}\text { Menjadi pendidik yang } \\
\text { kompeten dengan kegiatan } \\
\text { seminar ini }\end{array}$ & 5 \\
\hline \multicolumn{1}{c}{ Total responden } & $\mathbf{7 8}$ \\
\hline
\end{tabular}

Hasil penelitian ini secara umum berkonstribusi terhadap kegiatan webinar tentang disposisi berpikir.
Konstribusi hasil penelitian ini adalah memberikan gambaran awal tentang pengetahuan pendidik dan calon pendidik dalam memahami disposisi berpikir. Beberapa peneliti mengatakan bahwa penting untuk mengidentifikasi pemahaman awal, baik siswa maupun mahasiswa sebelum melaksanakan pembelajaran (Setiawan \& Mustangin, 2020b, 2020a), termasuk mengidentifikasi awal pemahaman peserta webinar tentang materi tertentu. Bahkan, apabila terjadi kesalahpahaman, maka kita dapat memperbaiki kesalahpahaman tersebut (Setiawan, 2020a, 2020c, 2020b; Setiawan et al., 2020b), termasuk dalam pelaksanaan webinar. Dengan demikian, pengetahuan awal peserta tentang disposisi berpikir ini dapat digunakan untuk merancang webinar tentang disposisi berpikir yang akan dilakukan.

Secara umum diperoleh bahwa gambaran awal dari pengetahuan pendidik atau calon pendidik terhadap disposisi berpikir masih berada pada kategori sangat rendah. Bahkan, pengetahuan di semua pertanyaan pada Tabel 2 masih berada pada kategori sangat rendah. Hal ini juga didukung oleh pendapat responden yang menunjukkan bahwa $50 \%$ dari responden tidak mengetahui tentang disposisi berpikir. Oleh sebab itu, rendahnya pengetahuan tentang disposisi berpikir ini penting untuk diatasi dengan adanya webinar yang membahas mengenai disposisi berpikir. Hasil penelitian menunjukkan bahwa seorang guru harus memahami disposisi berpikir agar berhasil dalam melakukan pembelajaran di kelas (Clark et al., 2014). Hal ini disebabkan pembelajaran yang dilakukan oleh guru dapat memengaruhi prestasi siswa (Setiawan, 2020e, 2020a) atau bahkan cara siswa dalam menyelesaikan masalah (Setiawan et al., 2020b). 
Dengan demikian, implikasi hasil penelitian ini terhadap kegiatan webinar tentang disposisi berpikir harus memuat kesebelas pertanyaan yang ada dalam Tabel 2. Selain itu, webinar yang dilaksanakan hendaknya juga memperhatikan pendapat-pendapat responden yang ingin memperoleh pengetahuan baru dari disposisi berpikir dan juga ingin memperdalam tentang disposisi berpikir. Oleh sebab itu, webinar yang akan dilakukan harus memuat pengetahuan tentang disposisi berpikir yang luas dan mendalam, sehingga harapan-harapan dari peserta webinar dapat terpenuhi.

\section{Kesimpulan dan Saran}

Dari hasil penelitian dapat disimpulkan bahwa pengetahuan responden terhadap disposisi berpikir masih sangat rendah, yaitu sebesar $38,45 \%$. Selain itu, juga diperoleh bahwa $50 \%$ responden belum mengetahui tentang disposisi berpikir dan $42 \%$ responden masih sedikit memiliki pengetahuan tentang disposisi berpikir. Ini artinya, dibutuhkan webinar tentang disposisi berpikir untuk mahasiswa calon guru matematika dan guru.

Oleh karena itu, kegiatan yang akan dilakukan oleh peneliti adalah mengadakan kegiatan pengabdian kepada masyarakat yang berupa webinar nasional tentang disposisi berpikir yang dibutuhkan oleh responden. Rancangan kegiatan webinar yang akan dilakukan berisi materi yang sesuai dengan pertanyaan-pertanyaan pada Tabel 2 . Dengan adanya webinar ini diharapkan responden, baik yang merupakan seorang pendidik maupun calon pendidik lebih memahami tentang disposisi berpikir. Dengan demikian, masalah ketidaktahuan tentang disposisi berpikir dapat diatasi.

\section{DAFTAR PUSTAKA}

Almerino, P. M., Etcuban, J. O., Jose, C. G. De, \& Almerino, J. G. F. (2019). Students' Affective Belief as the Component in Mathematical Disposition. International Electronic Journal of Mathematics Education, 14(3), 475-487. https://doi.org/https://doi.org/10.293 33/iejme/5750

Clark, L. M., Depiper, J. N., Frank, T. J., Nishio, M., Campbell, P. F., Smith, T. M., ... Choi, Y. (2014). Teacher Characteristics Associated With Mathematics Teachers' Beliefs and Awareness of Their Students' Mathematical Dispositions. Journal for Research in Mathematics Education, 45(2), 246-284.

Creswell, J. W. (2012). Educational Research Planning, Conducting and Evaluating Quantitative and Qualitative Research (Fourth). Boston: Pearson Education, Inc.

Hästö, P., Palkki, R., Tuomela, D., \& Star, J. R. (2019). Relati ionship between $b$ mathem matical fle exibility and suc ccess in nation nal exam minations s. European Journal of Science and Mathematics Education, 7(1), 1-13.

Karademir, C. A. (2019). Pre-Service Teachers' Problem Solving Skills and Curiosity Levels. International Journal of Educational Methodology, 5(1), 151-164. https://doi.org/10.12973/ijem.5.1.16 3

Kele, A., \& Sharma, S. (2014). Students' Beliefs About Learning Mathematics: Some Findings From the Solomon Islands. Teachers and Curriculum, 14(1), 33-44. https://doi.org/10.15663/tandc.v14i1 .92

Perkins, D. N., Jay, E., \& Tishman, S. (1993). Beyond Abilities: A Dispositional Theory of Thinking. 
Merril-Palmer Quarterly, 39(1), 121.

Rittle-Johnson, B., \& Star, J. R. (2007). Does Comparing Solution Methods Facilitate Conceptual and Procedural Knowledge? An Experimental Study on Learning to Solve Equations. Journal of Educational Psychology, 99(3), 561-574. https://doi.org/10.1037/00220663.99.3.561

Ron, S. (2001). From IQ to IC: A Dispositional View of Intelligence. Roeper Riview, 23(3), 1-23.

Setiawan, Y. E. (2020a). Analisis Kemampuan Siswa dalam Pembuktian Kesebangunan Dua Segitiga. Al-Khwarizmi: Jurnal Pendidikan Matematika Dan Ilmu Pengetahuan Alam, 8(1), 23-38. https://doi.org/http://dx.doi.org/10.2 4256/jpmipa.v8i1.80

Setiawan, Y. E. (2020b). Analisis Kesalahan Siswa dalam Menggeneralisasi Pola Linier. Jurnal Nasional Pendidikan Matematika, 4(2), 180-194. https://doi.org/http://dx.doi.org/10.3 3603/jnpm.v4i2.3386

Setiawan, Y. E. (2020c). Analisis Kesalahan Siswa dalam Menilai Kebenaran Suatu Pernyataan. Jurnal Didaktik Matematika, 7(1), 13-31. https://doi.org/10.24815/jdm.v7i1.1 4495

Setiawan, Y. E. (2020d). Disposisi Berpikir. Lumajang: CV. AlMukmin Yes.

Setiawan, Y. E. (2020e). Sistem Pendukung Pengambilan Keputusan Rekrutmen Guru Menggunakan Logika Fuzzy Tahani. Barekeng: Jurnal Ilmu Matematika Dan Terapan, 14(2), 259-272. https://doi.org/https://doi.org/10.305 98/barekengvol14iss2pp259-272
Setiawan, Y. E., \& Mustangin. (2020a). Kepraktisan Model Pembelajaran IDEA (Issue, Discussion, Establish, and Apply) dalam Pembelajaran Matematika. Aksioma: Jurnal Program Studi Pendidikan Matematika, 9(3), 776-788. https://doi.org/https://doi.org/10.241 27/ajpm.v9i3.2917

Setiawan, Y. E., \& Mustangin. (2020b). Validitas Model Pembelajaran IDEA ( Issue, Discussion, Establish, and Apply) untuk Meningkatkan Pemahaman Konsep. Jurnal Penelitian Pendidikan Dan Pengajaran Matematika, 6(1), 53-60. https://doi.org/https://doi.org/10.370 58/jp3m.v6i1.1432

Setiawan, Y. E., Purwanto, Parta, I. N., \& Sisworo. (2020). Generalization Strategy of Linear Patterns From Field-Dependent Cognitive Style. Journal on Mathematics Education, 11(1), 77-94. https://doi.org/http://doi.org/10.2234 2/jme.11.1.9134.77-94

Star, J. R., \& Rittle-Johnson, B. (2008). Flexibility in Problem Solving: The Case of Equation Solving. Learning and Instruction, 18(2008), 565-579. https://doi.org/10.1016/j.learninstruc .2007.09.018

Tishman, S., \& Andrade, A. (1995). Thinking Dispositions: A review of Current Theories, Practices, and Issues. Cambridge, MA: Harvard University Graduate School of Education.

Tishman, S., Jay, E., \& Perkins, D. N. (1993). Teaching Thinking Dispositions : From Transmission to Enculturation. Theory Into Practice, 32(3), 147-153. 